\title{
Novel Therapies in Hepatitis B and C
}

\author{
Bart Takkenberg, MD, Joep de Bruijne, MD, Christine Weegink, MD, PhD, \\ Peter Jansen, $M D, P h D$, and Hendrik Reesink, MD, PhD
}

\author{
Corresponding author \\ Hendrik Reesink, MD, PhD \\ Department of Gastroenterology and Hepatology, \\ Academic Medical Center, University of Amsterdam, \\ Meibergdreef 9, 1105 AZ Amsterdam, the Netherlands. \\ E-mail: H.W.Reesink@amc.nl
}

Current Gastroenterology Reports 2008, 10:81-90

Current Medicine Group LLC ISSN 1522-8037

Copyright (C 2008 by Current Medicine Group LLC

Chronic hepatitis B and C affect approximately 500 million people in the world, with substantial disease burden including liver cirrhosis and hepatocellular carcinoma. For chronic hepatitis B, two treatment strategies are currently available, both with suboptimal response and significant side effects. Promising new drugs are approaching the stage of approval; however, these agents still need further development to control this disease. Based on the understanding of the hepatitis C virus life cycle, new treatment developments for chronic hepatitis $\mathrm{C}$ tend to succeed rapidly; therefore, it is only a matter of time before new therapies emerge. This review summarizes the most important new agents available for treatment of chronic hepatitis B and C.

\section{Introduction}

Chronic hepatitis B and C affect $9 \%$ of the world population; of these approximately 500 million people, $6 \%$ have chronic hepatitis $\mathrm{B}$ and $3 \%$ have chronic hepatitis $\mathrm{C}$ [1]. Worldwide, it is estimated that $57 \%$ of cirrhosis is due to either hepatitis B virus (HBV) $(30 \%)$ or hepatitis C virus (HCV) (27\%) [2]. In hepatocellular carcinoma, 78\% of cases are attributable to both viruses, in which $\mathrm{HBV}$ accounts for $53 \%$ and $\mathrm{HCV}$ for $25 \%$. Mortality estimation models estimate approximately 366,000 deaths are due to HCV each year and 563,000 to 620,000 deaths are due to $\mathrm{HBV}$, thereby making chronic hepatitis $\mathrm{B}$ the ninth leading cause of death in the world [2-4].

In the past decade, therapeutic options for chronic hepatitis B and C have dramatically improved. This has resulted in more $\mathrm{HCV}$ patients achieving a sustained virological response and more chronic hepatitis $B$ patients achieving a state of inactive disease. Unfortunately, treatment of both infections is not yet optimal, especially in chronic hepatitis B, for which a cure is still far away.
This article summarizes new treatment options for both chronic hepatitis B and C.

\section{Chronic Hepatitis B}

Therapeutic aims and response definitions

The primary aim in treating chronic hepatitis B is reducing liver cell inflammation and progression of fibrosis before cirrhosis and hepatocellular carcinoma develop. This is done by suppressing HBV replication and inducing hepatitis $\mathrm{B} \mathrm{e}$ antigen ( $\mathrm{HBeAg}$ ) seroconversion in $\mathrm{HBeAg}$-positive chronic hepatitis $\mathrm{B}$ patients. Because the natural course in chronic hepatitis B is typically silent and asymptomatic until cirrhosis or hepatocellular carcinoma develops, the problem lies in detecting which patients need treatment. Indications for treatment include alanine aminotransferase (ALT) levels greater than two times the upper limit of normal for more then 6 months, with HBV DNA levels greater than 20,000 IU/mL. In some chronic hepatitis B patients who do not fully meet these criteria, a liver biopsy can help decide if treatment is indicated.

Two treatment strategies are available that affect different steps in the HBV life cycle. Immunomodulatory therapy consists mainly of pegylated interferon- $\alpha$ (IFN- $\alpha$ ), which enhances the host immune response against HBVinfected hepatocytes. There are also nucleoside/nucleotide analogues that interfere directly with the life cycle of HBV by inhibiting reverse transcription.

Standardization of terminology and definitions for therapy end points is of utmost importance. Biochemical responses are generally defined as decreases in serum ALT levels to the normal range $(\leq 45 \mathrm{U} / \mathrm{L})$. Histological responses are usually defined as at least a two-point decrease in histological activity index with no worsening of fibrosis between pretreatment and end-of-treatment liver biopsies. A virological response is defined as loss of HBV DNA in serum measured by polymerase chain reaction assays, and loss of $\mathrm{HBeAg}$ in patients who were initially $\mathrm{HBeAg}$ positive. Response is complete when hepatitis B surface antigen ( $\mathrm{HBs} \mathrm{Ag}$ ) has disappeared and anti-HBs antibodies have appeared. A viral response is sustained when it has been maintained for more than 6 months after stopping therapy. Virological breakthrough is defined as a $1-\log _{10}$ increase in HBV DNA during treatment, indicating virological resistance. When ALT levels during treatment also rise, it is called biochemical breakthrough [5-7]. 


\section{Current therapeutic options}

Table 1 outlines the various treatment options currently available for chronic hepatitis $B$ and details their response outcomes $[6,8-13,14 \bullet \bullet, 15 \bullet, 16-18]$.

\section{Standard IFN- $\alpha$}

IFN- $\alpha$ has antiviral, antiproliferative, and immunomodulatory effects, and is widely used in the treatment of viral hepatitis. IFN- $\alpha$ is administered three times weekly in 5to 10 -MIU doses for the duration of 4 to 6 months.

In 1993, a meta-analysis demonstrated that $\mathrm{HBeAg}$ positive chronic hepatitis B subjects treated with IFN- $\alpha$ had significantly better results in terms of HBsAg loss (8\%), HBeAg loss (33\%), and undetectable HBV DNA levels (37\%) [8]. A more recent study demonstrated about the same results, but also reported an HBeAg seroconversion of $19 \%$ and improvement of histological activity of 46\% [9].

Clinical trials with $\mathrm{HBeAg-negative} \mathrm{chronic} \mathrm{hepati-}$ tis $\mathrm{B}$ patients have also been described, but all have had smaller numbers of patients (Table 1). About half of the patients relapsed when treatment was discontinued.

\section{Pegylated IFN- $\alpha$ (peginterferon- $\alpha$ )}

Pegylation of IFN- $\alpha$ with a $12-$ or $40-\mathrm{kD}$ polyethylene glycol molecule prolongs the half-life of IFN- $\alpha$. This causes an increase of systematic exposure and biological effect. Currently, only peginterferon alfa-2a (Pegasys, Hoffman-La Roche Inc., Nutley, NJ) is registered for the treatment of $\mathrm{HBeAg}$-positive and -negative chronic hepatitis B. Peginterferon alfa-2a provokes a higher sustained virological response than standard IFN- $\alpha$ and has the advantage of more convenient administration.

A phase 2 trial comparing peginterferon alfa- $2 \mathrm{a}(180 \mu \mathrm{g}$ weekly) with standard IFN- $\alpha$ (4.5 MIU three times weekly) for 24 weeks in HBeAg-positive chronic hepatitis B patients showed a twofold higher response in HBeAg loss, HBV DNA suppression, and ALT normalization [19]. Two randomized controlled trials described an $\mathrm{HBeAg}$ seroconversion in approximately one fourth of the patients, with loss of HBsAg in about $3 \%$ of the patients $[10,11]$. One study showed that patients with genotypes $\mathrm{A}$ and $\mathrm{B}$ responded better than those with genotypes $\mathrm{C}$ and $\mathrm{D}$ [11]. Other predictors of $\mathrm{HBeAg}$ seroconversion are high pretreatment ALT levels and lower levels of HBV DNA. In HBeAg-negative patients, 48-week treatment with peginterferon- $\alpha$ resulted in a $36 \%$ sustained virological response at week 72 [16]. Pilot studies suggesting higher rates of sustained virological response in this group of patients with longer treatment duration (eg, for 60 weeks) are under way [20].

\section{Lamivudine}

Lamivudine is an oral nucleoside analogue with a strong $\mathrm{HBV}$ inhibitory effect. In a study of HBeAg-positive chronic hepatitis B patients, about $20 \%$ achieved HBeAg seroconversion and $50 \%$ had histological improvement after 1 year of treatment with lamivudine (100 mg daily) monotherapy
[12]. For HBeAg-negative chronic hepatitis B patients, undetectable HBV DNA $(<2.5 \mathrm{pg} / \mathrm{mL})$ appears in about $60 \%$ of the patients and histological improvement is nearly the same [21]. However, a great disadvantage of lamivudine is the rapid emergence of its resistance in the YMDD motif, which develops in $24 \%, 38 \%, 49 \%$, and $68 \%$ of patients after 1,2 , 3 , and 4 years, respectively. This has clinical implications for future nucleotide analogue therapy $[5,12,22]$.

\section{Adefovir dipivoxil}

Adefovir dipivoxil is an oral adenine nucleotide analogue that inhibits HBV polymerase and reverse transcriptase. In HBeAg-positive chronic hepatitis B patients, $10 \mathrm{mg}$ of adefovir daily led to HBeAg seroconversion in $12 \%$, with histological improvement in 53\% and undetectable HBV DNA (< 400 copies $/ \mathrm{mL})$ in $21 \%$ [13]. In HBeAgnegative chronic hepatitis $\mathrm{B}$ patients, $51 \%$ had undetectable HBV DNA levels and $64 \%$ had histological improvement [19]. Virological resistance after 5 years of treatment in HBeAg-negative chronic hepatitis B patients was $29 \%$ (1 year $0 \%, 2$ years $3 \%, 3$ years $11 \%$, and 4 years $18 \%$ ) [5]. Furthermore, adefovir is highly active in lamivudine-resistant chronic hepatitis B $[23,24]$.

\section{Entecavir}

Entecavir is an oral deoxyguanosine analogue with potent activity against $\mathrm{HBV}$. In $\mathrm{HBeAg}$-positive and -negative chronic hepatitis B patients, 1-year treatment with entecavir $0.5 \mathrm{mg}$ daily resulted in significantly higher virological, biochemical, and histological responses than lamivudine treatment (Table 1). Entecavir did not result in higher rates of HBeAg seroconversion $[14 \bullet \bullet, 18]$. In a phase 3 study in lamivudine-refractory $\mathrm{HBeAg}$-positive chronic hepatitis B patients, entecavir $1.0 \mathrm{mg}$ daily for 1 year resulted in only $19 \%$ undetectable HBV DNA levels (<300 copies $/ \mathrm{mL}$ ) and 1.4\% entecavir resistance [22].

\section{Telbivudine}

Telbivudine is an HBV-specific L-nucleoside analogue of thymidine and has been recently approved by the US Food and Drug Administration for the treatment of $\mathrm{HBeAg}$ positive chronic hepatitis B in the United States. A phase 3 clinical trial comparing telbivudine 400 and $600 \mathrm{mg}$ with lamivudine $100 \mathrm{mg}$ and telbivudine/lamivudine combination therapy showed that telbivudine monotherapy resulted in significantly higher mean reduction in HBV DNA levels (6.01 vs $4.57 \log _{10}$ ) than lamivudine, with more patients attaining undetectable HBV DNA (61\% vs $32 \%$ ), ALT normalization $(86 \%$ vs $63 \%)$, and greater HBeAg seroconversion rate $(31 \%$ vs $22 \%)$ at week 52 . After 1 year, resistance was $4.5 \%$ in the telbivudine group [15•].

\section{Agents in late-stage development \\ Tenofovir}

Tenofovir disoproxil fumarate, a nucleotide analogue, is licensed for the treatment of HIV at an oral dose of 300 


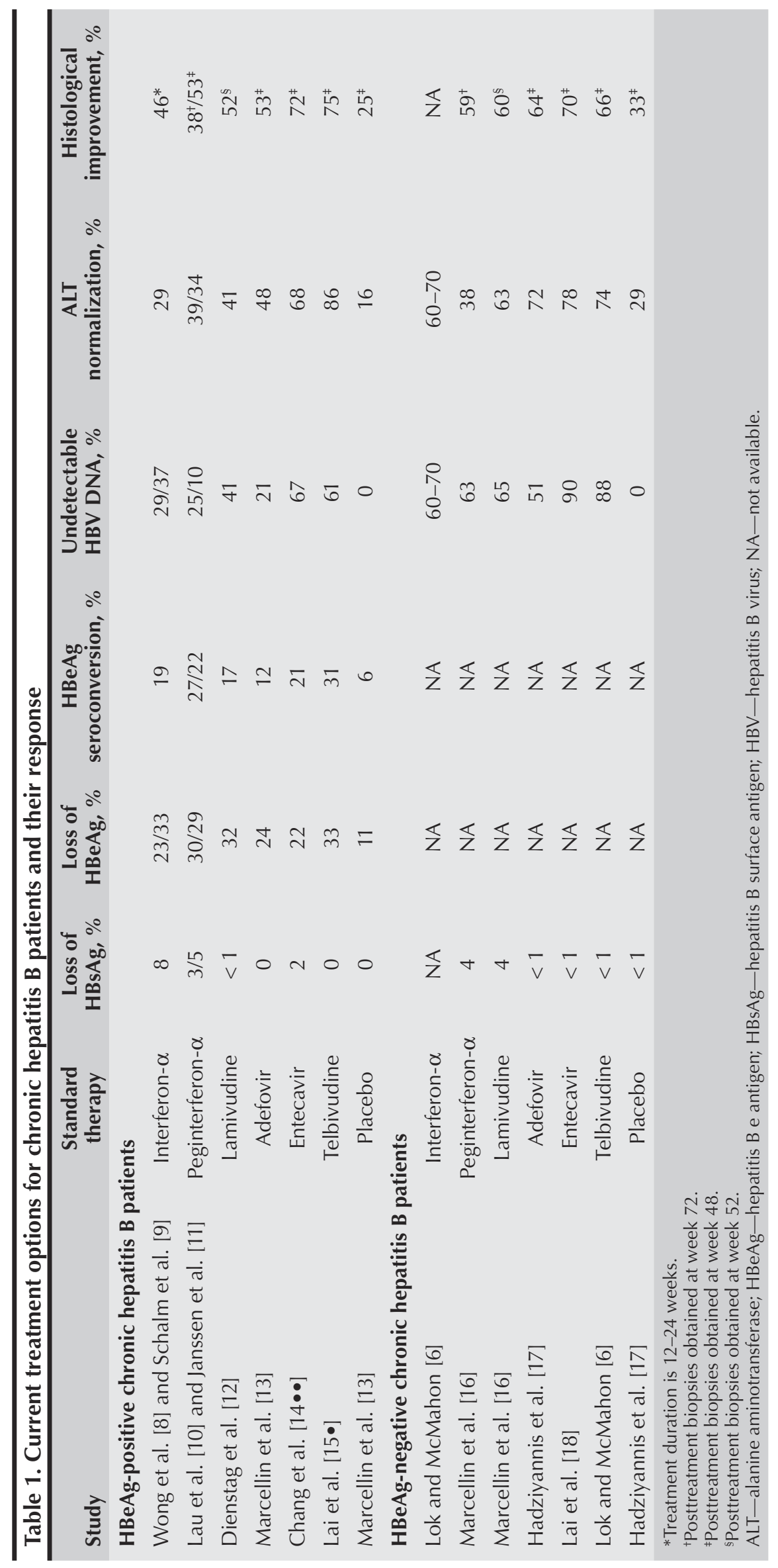


mg daily and has a strong antiviral activity with a favorable safety profile. From studies in HIV/HBV-coinfected patients, tenofovir appeared to also have a strong inhibitory effect on HBV replication, with a mean 4- to $5-\log _{10}$ decrease in HBV DNA after 48 weeks of treatment $[25,26]$. Two small phase 3 trials showed that tenofovir has stronger antiviral activity than adefovir in lamivudine-resistant chronic hepatitis B, with no resistance yet described. Results of large phase 3 trials in chronic hepatitis B patients not coinfected with HIV are under way $[27 \bullet \bullet, 28]$.

\section{Emtricitabine (FTC)}

Emtricitabine is a cytosine analogue of deoxycytidine triphosphate that is structurally similar to lamivudine and is a potent inhibitor of HIV and HBV replication. In a phase 3 trial, emtricitabine $200 \mathrm{mg}$ was given daily for 48 weeks in HBeAg-positive and -negative chronic hepatitis B patients; histological improvement appeared in $63 \%$ and $59 \%$, respectively. Sixty-five percent of both $\mathrm{HBeAg}$-positive and -negative chronic hepatitis $\mathrm{B}$ patients had normalized ALT levels. Undetectable HBV DNA $(<400$ copies $/ \mathrm{mL}$ ) was measured in $39 \%$ and $79 \%$ of patients, respectively, but there was no difference in $\mathrm{HBeAg}$ seroconversion rate as compared with the placebo group. Overall, due to mutations in the YMDD motif, emtricitabine treatment resulted in resistance in $13 \%$ of the chronic hepatitis B patients. Most patients in this trial were $\mathrm{HBeAg}$ positive and showed $17 \%$ resistance after 1 year of treatment [29].

\section{Clevudine}

Clevudine is a nucleoside analogue with potent activity against $\mathrm{HBV}$ and some activity against Epstein-Barr virus. Two phase 3 clinical trials have been published in which the efficacy of 24 weeks of treatment with clevudine was compared with placebo in both $\mathrm{HBeAg}$-positive and -negative chronic hepatitis $\mathrm{B}$ patients. In the $\mathrm{HBeAg}$ positive patients, 24 weeks of clevudine $30 \mathrm{mg} / \mathrm{d}$ showed a mean $5.10-\log _{10}$ reduction in HBV DNA level, with 59\% attaining undetectable HBV DNA $(<300$ copies $/ \mathrm{mL}$ ), $68 \%$ attaining ALT normalization, and $8 \%$ attaining HBeAg seroconversion. No viral resistance was reported and clevudine was well tolerated [30].

In HBeAg-negative chronic hepatitis B patients, 24 weeks of clevudine $30 \mathrm{mg} / \mathrm{d}$ showed a $4.25-\log _{10}$ reduction in HBV DNA level, with $92 \%$ attaining undetectable HBV DNA (<300 copies $/ \mathrm{mL}$ ) and $75 \%$ attaining ALT normalization. This study also reported no viral resistance, and clevudine was well tolerated [31]. Because clevudine was studied for only 24 weeks, little can be said about the incidence of resistance development in longer treatment durations.

\section{Pradefovir}

Pradefovir is a prodrug of 9-(2-phosphonylmethoxyethyl) adenine (PMAE). PMAE is a phosphonate analogue of adenine that is effective against HBV. Pradefovir is activated by CYP3A4, which is located mainly in the liver, resulting in high intrahepatic metabolite concentrations and thereby preventing systemic side effects (eg, nephrotoxicity). A phase 1 trial showed that pradefovir was well tolerated, with high levels of PMAE but lower levels in the kidney, suggesting less nephrotoxicity. Phase 2 and 3 trials are currently in development [32].

\section{Valtorcitabine}

Valtorcitabine is a prodrug of telbivudine that has demonstrated potent suppression of serum HBV DNA in HBeAg-positive patients. In a phase $1 / 2$ dose-escalation study that evaluated valtorcitabine $300,600,900$, and $1200 \mathrm{mg} / \mathrm{d}$ for 28 days, valtorcitabine $900 \mathrm{mg} / \mathrm{d}$ produced a mean reduction in serum HBV DNA level of $3.04 \log _{10}$ copies/mL after only 4 weeks of treatment. Valtorcitabine was well tolerated in all patient groups, with a safety profile comparable with that of placebo [33].

\section{Chronic Hepatitis C}

\section{Hepatitis $\mathrm{C}$ antiviral therapies}

The current standard of care for patients with chronic hepatitis $C$ is a combination of peginterferon- $\alpha$ and ribavirin. This results in a sustained virological response in approximately $80 \%$ of patients infected with HCV genotype $2 / 3$ and less than $50 \%$ with HCV genotype 1 [34,35]. Genotype 1 causes more than $60 \%$ of HCV infections in Europe and Asia and more than $70 \%$ of HCV infections in the United States, and is therefore the most prevalent genotype worldwide. The current standard of care is expensive, requires at least 24 to 48 weeks of treatment, and is associated with significant adverse effects. Thus, new therapies resulting in a higher rate of sustained virological response and fewer adverse effects are highly desirable.

Recently, major progression in cell culture systems and replication assays has advanced the in vitro propagation and production of infectious HCV [36,37••]. This has accelerated the development of new classes of antiviral drugs, including specifically targeted antiviral therapy for hepatitis C (STAT-C), which are expected to improve the current standard of care. These antiviral drugs inhibit different phases in the HCV life cycle or modulate the immune response [38]. Many antiviral drugs and immune modulators are being tested in preclinical settings and phase 1,2, and 3 clinical trials (Table 2). These novel HCV therapies are reviewed below following our description of the steps of the HCV life cycle (Fig. 1) [39].

\section{Early steps of infection}

Viral attachment, entry, and fusion involve two groups of molecules and proteins. The first group comprises the HCV structural envelope glycoproteins, E1 and E2 [40]. These are transmembrane glycoproteins at the surface of the HCV virion envelope [41]. Whereas E1 is thought to 


\begin{tabular}{|c|c|c|c|}
\hline Drug type & Compound & Manufacturer & $\begin{array}{l}\text { Development } \\
\text { phase }\end{array}$ \\
\hline \multicolumn{4}{|l|}{ Phase 1: Early steps of infection } \\
\hline Polyclonal immunoglobulins & Civacir (HCIG) & Nabi Biopharmaceuticals (Boca Raton, FL) & 2 \\
\hline \multirow[t]{2}{*}{ Monoclonal antibodies } & HCV-AB65; HCV-AB68 & XTL Biopharmaceuticals (Rehovot, Israel) & 2 \\
\hline & XTL6865 & XTL Biopharmaceuticals (Rehovot, Israel) & Halted \\
\hline \multicolumn{4}{|l|}{ Phase 2: HCV RNA translation } \\
\hline \multirow[t]{2}{*}{ Antisense oligonucleotides } & AVI-4065 & AVI BioPharma (Portland, OR) & 2 \\
\hline & ISIS 14803 & Isis Pharmaceuticals (Carlsbad, CA) & Halted \\
\hline Ribozyme & Heptazyme & Ribozyme Pharmaceuticals (San Francisco, CA) & Halted \\
\hline IRES inhibitor & VGX-410C & VGX Pharmaceuticals (Blue Bell, PA) & 2 \\
\hline \multirow[t]{2}{*}{ Small inhibitory RNA } & TT 033 & Tacere Therapeutics (San Jose, CA) & Preclinical \\
\hline & Sirna-034 & Sirna Therapeutics (San Francisco, CA) & Preclinical \\
\hline \multicolumn{4}{|c|}{ Phase 3: Posttranslational processing } \\
\hline \multirow[t]{7}{*}{ NS3 serine protein inhibitors } & SCH 503034 & Schering-Plough (Kenilworth, NJ) & 2 \\
\hline & Telaprevir (VX-950) & Vertex Pharmaceuticals (Cambridge, MA) & 2 \\
\hline & TMC435350 & $\begin{array}{l}\text { Tibotec (Mechelen, Belgium) and Medivir } \\
\text { (Huddinge, Sweden) }\end{array}$ & 2 \\
\hline & ITMN-191 & InterMune Inc. (Brisbane, CA) & 1 \\
\hline & BILN-2061 & Boehringer-Ingelheim (Ingelheim, Germany) & Halted \\
\hline & ACH-806 (GS-9132) & Achillion Pharmaceuticals (New Haven, CT) & Halted \\
\hline & $\mathrm{ACH}-1095$ & Achillion Pharmaceuticals (New Haven, CT) & Preclinical \\
\hline \multicolumn{4}{|l|}{ Phase 4: HCV replication } \\
\hline \multirow[t]{10}{*}{ NS5B polymerase inhibitors } & HCV-796 & $\begin{array}{l}\text { ViroPharma (Exton, PA) and Wyeth } \\
\text { (Madison, NJ) }\end{array}$ & 2 \\
\hline & R1626 & Roche (Basel, Switzerland) & 2 \\
\hline & R7128; R1479 & Roche (Basel, Switzerland) & 1 \\
\hline & MK-0608 & Merck (Whitehouse Station, NJ) & 1 \\
\hline & ANA598 & Anadys Pharmaceuticals (San Diego, CA) & 1 \\
\hline & A-782759 & Abbott Laboratories (Abbott Park, IL) & 1 \\
\hline & JTK-003; JTK-109 & Akros Pharma (Princeton, NJ) & Halted \\
\hline & R-803 & Roche (Basel, Switzerland) & Halted \\
\hline & XTL-2125 & XTL Biopharmaceuticals (Rehovot, Israel) & Halted \\
\hline & GL59728; GL60667 & GeneLabs Technologies (Redwood City, CA) & Preclinical \\
\hline \multirow[t]{2}{*}{ Cyclophilin B inhibitors } & DEBIO-025 & Debiopharm (Lausanne, Switzerland) & 2 \\
\hline & NIM811 & Novartis Pharma (Basel, Switzerland) & 1 \\
\hline \multirow[t]{2}{*}{ NS5A inhibitors } & A-831 & Arrow Therapeutics (London, UK) & 1 \\
\hline & A-689 & Arrow Therapeutics (London, UK) & Preclinical \\
\hline NS3 RNA helicase inhibitor & QU 663 & BioBlocks Inc. (San Diego, CA) & Preclinical \\
\hline \multicolumn{4}{|c|}{ Phase 5: Viral assembly and release } \\
\hline \multirow[t]{2}{*}{ Glucosidase inhibitors } & Celgosivir (MX-3253) & Migenix Inc. (Vancouver, Canada) & 2 \\
\hline & UT-231B & United Therapeutics (Silver Spring, MD) & Halted \\
\hline
\end{tabular}




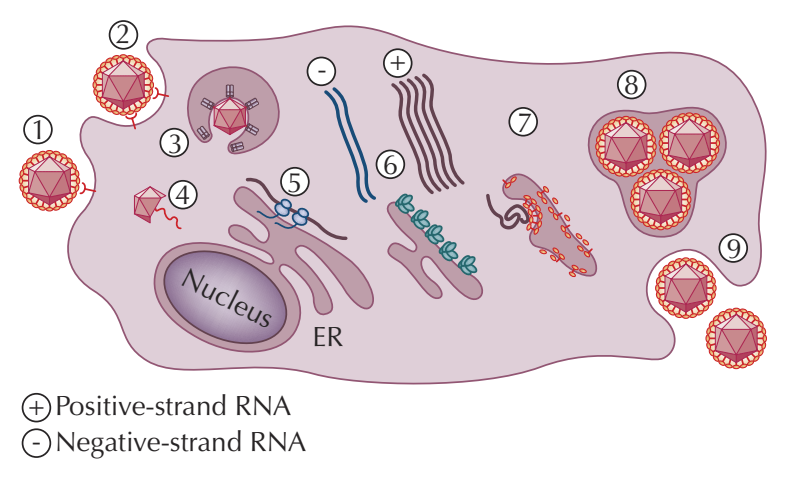

Figure 1. The hepatitis $C$ virus (HCV) life cycle. (1) Virus binding to cellular receptor(s) (small molecule inhibitors of cell attachment, monoclonal antibodies, hyperimmune anti-HCV immunoglobulins); (2) receptor-mediated endocytosis; (3) membrane fusion and nucleocapsid release; (4) nucleocapsid uncoating; (5) translation and polyprotein processing (internal ribosome entry site inhibitors, NS3 serine protease inhibitors, NS2 zinc-dependent autoprotease inhibitors); (6) HCV RNA replication (NS5B RNA-dependent RNA polymerase inhibitors, NS5A inhibitors, inhibitors of replication complex formation); (7) virion formation and budding in intracellular vesicles; (8) virion transport and maturation; (9) virion release. ER-endoplasmic reticulum. (From Penin [39].)

be responsible for mediating the intracytoplasmic virus membrane fusion, E2 is involved in the initiating process of binding to target cells [42]. The second group consists of several receptor molecules on the hepatocytes. These molecules (CD81, claudine-1, scavenger receptor class B type 1 , and dendritic cell-specific intercellular adhesion molecule 3-grabbing nonintegrin) are thought to mediate HCV binding and internalization and may act as potential targets for anti-HCV drugs.

Although many potential targets have been identified, only a few clinical trials have been performed using viral attachment as a target. HCV-AB68 (XTL Biopharmaceuticals, Rehovot, Israel), is a human monoclonal antibody against the envelope protein E2 of HCV [43]. HCV-AB68 has been tested in phase $1 \mathrm{~b}$ and 2 clinical trials for safety, tolerability, and antiviral activity using HCV-infected liver transplant recipients.

Civacir (Nabi Biopharmaceuticals, Boca Raton, FL), a human hepatitis $\mathrm{C}$ antibody-enriched immune globulin, has been tested in two phase 2 clinical trials with HCVinfected liver transplant recipients. The result of one randomized, open-label study using two different dosages for 14 weeks showed that HCV RNA levels were not suppressed [44].

\section{HCV RNA translation/polyprotein synthesis}

The HCV genome translation initiation is directed by an internal ribosome entry site that recruits cellular and viral proteins. After these proteins liberate free RNAs in the cell cytoplasm by decapsidation of viral nucleocapsids, they serve as messenger RNAs (mRNA) for synthesis of the HCV polyprotein.
Several potential antiviral approaches have been developed in various in vitro systems to inhibit HCV RNA translation. Ribozymes recognize and catalyze the cleavage of target RNA molecules. Heptazyme (Ribozyme Pharmaceuticals, San Francisco, CA), a chemically modified and stabilized ribozyme, was being tested in preclinical trials; however, the trial was halted in 2000 due to animal toxicity. To date, no other trials on ribozymes have been reported.

The second group comprises antisense DNA or RNA oligonucleotides. The sequence of these oligonucleotides is complementary to the target mRNA and they prevent the construction of regulatory sequences and/or structures important for efficient translation of $\mathrm{HCV}$ polyprotein [45]. Recently, two antisense oligonucleotide inhibitors have been tested. A phase 1 clinical trial testing ISIS 14803 (Isis Pharmaceuticals, Carlsbad, CA) was halted because of lack of antiviral efficacy and concerns of transient elevated liver enzymes [46].

Specific small molecule inhibitors of the HCV internal ribosome entry site are the third group of drugs potentially able to inhibit HCV RNA translation. As mentioned above, the HCV internal ribosome entry site directly regulates the assembly of translation initiation complexes on viral mRNA by recruiting cellular and viral proteins [47]. Currently, two phase 2 clinical trials are under way in which $\mathrm{HCV}$-infected patients are receiving VGX-410C (VGX Pharmaceuticals, Blue Bell, PA), a ribosome formation inhibitor, in various doses. No results have been published to date.

\section{Posttranslational processing}

The HCV genome encodes a single polyprotein and is then processed into 10 mature structural and regulatory proteins. The processing of the structural proteins (E1, $\mathrm{E} 2$, core protein, and $\mathrm{p} 7$ ) requires at least two host cellular peptidases. The regulatory proteins are processed by a virus-specific helicase, polymerase, and proteases. Polyprotein processing of positive-stranded HCV RNA by the various peptidases is important in the regulation of gene production and replication [48]. Because of the critical function of these proteins in the viral life cycle, they represent attractive targets for STAT-C.

BILN-2061 (Boehringer-Ingelheim, Ingelheim, Germany), an NS3 protease inhibitor preventing cleavage of the NS3/4 part of the polyprotein, was the first HCV NS3/4A protease inhibitor to enter human clinical trials. BILN2061 was highly effective, inducing a rapid $3-\log _{10}$ decline in virus load in all treated patients with HCV genotype 1 within 2 days, and reaching undetectable levels within 24 to 28 hours after administration in some patients. However, the study was halted because of myocardial toxicity in apes [49]. Telaprevir (VX-950; Vertex Pharmaceuticals, Cambridge, MA), another NS3/4A serine protease inhibitor, has recently been tested in a placebo-controlled, double-blind phase $1 \mathrm{~b}$ clinical trial. Telaprevir was well 
tolerated and had substantial antiviral effects. All $28 \mathrm{HCV}$ genotype 1 patients had a decline of at least $2 \log _{10}$ in HCV RNA from baseline, and 26 (93\%) of these 28 patients showed a decline of at least $3 \log _{10}$. The highest plasma drug concentration was reached in the group dosed with $750 \mathrm{mg}$ every 8 hours, and the median HCV RNA reduction in this group was $-4.4 \log _{10}$ after 14 days [50 ]. Viral breakthrough occurred in a substantial number of patients due to variant selection with decreased sensitivity to telaprevir. Resistant variants were mainly seen in lower-dose groups (450 mg every 8 hours) [51]. The rapid selection of resistant $\mathrm{HCV}$ isolates during telaprevir therapy indicates that combination treatment with peginterferon- $\alpha$ or other antiviral drugs will probably be necessary to avoid drug resistance. Subsequently, the group dosed with telaprevir $750 \mathrm{mg}$ every 8 hours was continued with peginterferon- $\alpha$ for 14 days, which resulted in median HCV RNA decline of $-5.5 \log _{10}$. No viral breakthrough was observed in this patient group. Twelve weeks after starting off-study standard therapy, HCV RNA was undetectable in all patients in the telaprevir and peginterferon- $\alpha$ combination group [52•]. Subsequently, several phase 2 placebo-controlled, randomized trials (PROVE 1, 2, and 3) testing telaprevir in combination with peginterferon- $\alpha$ with or without ribavirin were started. These trials included treatment-naive and nonresponse patients with HCV genotype 1 who received telaprevir treatment for 12 or 24 weeks in combination with peginterferon- $\alpha$ and ribavirin.

SCH 503034 (Schering-Plough, Kenilworth, NJ), a novel HCV NS3 protease inhibitor, showed potential antiviral properties in vivo. In a phase $1 \mathrm{~b}$, randomized, two dose-level, three-way cross-over, multicenter study, virologic response and tolerability of SCH 503034 were investigated in patients with HCV genotype 1 . The included patients were nonresponders to previous treatment with peginterferon alfa- $2 \mathrm{~b}$ with or without ribavirin. All patients $(n=26)$ received three dosing periods, each followed by a washout period of at least 2 weeks. The three dosing periods consisted of 1 week of SCH 503034 monotherapy ( 200 or $400 \mathrm{mg}$ ), 2 weeks of peginterferon alfa-2b monotherapy, and 2 weeks of SCH 503034 and peginterferon alfa- $2 \mathrm{~b}$ combination therapy. The highest decline in HCV RNA plasma levels was detected in the highest SCH 503034 dose group $(400 \mathrm{mg}$ ) in combination with peginterferon alfa-2b after 2 weeks. SCH 503034 in combination with peginterferon- $\alpha$ showed a mean maximum $\log _{10}$ change of -2.88 , compared with -1.61 (200 mg) and $-1.26(400 \mathrm{mg})$ changes in monotherapy [53].

More phase 1 and 2 clinical trials testing treatmentnaive and treatment-experienced patients with and without combination of peginterferon alfa- $2 \mathrm{~b}$ and ribavirin and higher doses of SCH 503034 are ongoing.

\section{$\mathrm{HCV}$ replication}

The mechanisms by which various viral and cellular components and RNA strands regulate HCV replication are complicated and not entirely understood. Three main phases in the HCV replication process can be identified. First, negative-strand RNA is synthesized by using positive-strand RNA as a template. The newly synthesized negative RNA strands serve as templates to produce many positive RNA strands in phase 2 . Phase 3 is characterized by positive polarity strands that are used for polyprotein processing, synthesis of new intermediates of replication, or packaging into new virus particles [54]. NS5B RNA-dependant RNA polymerase ( $\mathrm{RdRp}$ ) is a crucial viral component for negativeand positive-strand HCV RNA replication. The structure of this RdRp domain consists of a fully encircled active site formed by the classical three finger-palm-thumb subdomains. HCV regulatory proteins (NS5A, NS3 helicase-NTPase, NS4B) together with cellular components (cyclophilin B) form a complex mechanism to bind, activate, and catalyze NS5B RdRp. Currently two categories of RdRp inhibitors are being evaluated in clinical trials. The catalytic site of the RdRp-where nonnucleoside inhibitors target the allosteric site of the RdRp-forms an interesting target for nucleoside/nucleotide inhibitors. Valopicitabine (NM283; Idenix Pharmaceuticals, Cambridge, MA and Novartis, Basel, Switzerland) and R1626 (Roche Products, Basel, Switzerland) are both nucleoside analogues being tested in phase $1 \mathrm{~b}$ trials. Valopicitabine monotherapy ( $800 \mathrm{mg}$ for 2 weeks) showed an average dose-dependent HCV RNA decrease of $1.2 \log _{10}$ in HCV genotype 1-infected patients. An ongoing phase 2 clinical trial is comparing HCV genotype 1 nonresponders with previous IFN-based therapy patients receiving valopicitabine alone, valopicitabine with peginterferon- $\alpha$, or peginterferon- $\alpha$ with ribavirin for 48 weeks. Results at week 24 showed a dose-dependent additive effect of valopicitabine to peginterferon- $\alpha$, including a significant number of patients with undetectable HCV RNA levels [55]. However, valopicitabine is no longer being studied due to its overall risk/benefit profile.

In another phase 1 study, HCV genotype 1-infected patients received R1626 1500, 3000, and $4500 \mathrm{mg}$ twice daily for 2 weeks. HCV RNA levels were reduced by -1.2, -2.6 , and $-3.7 \log _{10}$, respectively, making this the largest hepatitis $\mathrm{C}$ viral load drop for this class of STAT-C. However, both drugs were associated with significant side effects. The NM283 dosage had to be reduced due to gastrointestinal side effects and high dosages of R1626 were associated with anemia and other side effects [56].

HCV-796 (ViroPharma, Exton, PA, and Wyeth Pharmaceuticals, Madison, NJ) is a nonnucleoside allosteric site D inhibitor of the HCV RdRp. A phase 1 doseescalation study showed a $-1.4 \log _{10}$ HCV RNA level reduction within the highest-dose group. A subsequent phase 2 study was halted due to clinically significant elevated liver enzymes, including those in two patients who had to withdraw because of serious adverse events.

In addition to the many nucleoside/nucleotide and nonnucleoside inhibitors, NS5A and cyclophilin B inhibitors are being tested in ongoing trials. 


\section{Virus assembly and release}

No appropriate study model exists to assess the mechanisms of HCV assembly and release. The viral capsid is thought to be formed by structural core protein. Several structural proteins have been detected within the endoplasmic reticulum and the Golgi apparatus, and both organelles may be involved in later steps of virus assembly. The interaction between core protein and genomic RNA is probably the process that initiates viral particle formation. Targets for HCV antiviral drugs to inhibit virus assembly are based upon the assumption that a certain degree of glucosylation is needed for envelope proteins to cross cellular membranes. Iminosugars inhibit cellular glucosidases, resulting in the hyperglucosylation of envelope proteins, which inhibits their ability to cross membranes [57]. Two glucosidase inhibitors, UT-231B (United Therapeutics, Silver Spring, MD) and MX-3253 (Migenix, Vancouver, Canada), have been tested in phase 1 clinical trials. Both studies reported modest antiviral effects $[58,59]$ and these agents have since entered phase 3 study evaluation.

\section{Novel immunomodulatory agents}

At present, peginterferon- $\alpha$ with ribavirin is the only combination known to permanently eliminate $\mathrm{HCV}$ RNA levels and improve liver histology. Therefore peginterferon- $\alpha$ treatment, together with ribavirin, is currently the standard of care for HCV-infected patients. Several immune modulators are being tested to improve the outcome of current standard of care, reduce side effects, and lower treatment costs. Several modifications to the IFN proteins have resulted in long-acting (Albuferon, Human Genome Sciences, Rockville, MD), controlled-release (Locteron, OctoPlus NV, Leiden, Netherlands and Biolex Therapeutics, Pittsboro, NC), and orally administered (Belerofon, Angel Biotechnology, Edinburgh, Scotland, and Nautilus Biotech, Evry, France) IFNs. These modifications should increase the IFN plasma levels and lead to longer dosing intervals and better response rates. The long-acting and oral IFNs have the potential to replace current peginterferon- $\alpha$-based therapies in the future.

Ribavirin, the other component of standard-of-care treatment, is associated with significant hemolytic anemia, which may require dose reduction, discontinuation, or treatment with recombinant human erythropoietin or even blood transfusion. However, dose reduction of ribavirin is associated with a decrease of sustained virological response rates, making ribavirin analogues, with less side effects, attractive alternatives.

Viramidine (taribavirin; Valeant Pharmaceuticals International, Aliso Viejo, CA), is a ribavirin analogue that has been tested in a phase 2 clinical trial. Peginterferon alfa-2a with either ribavirin or Viramidine showed sustained virological response rates of $37 \%$ in the optimal dose group for Viramidine and $44 \%$ in the ribavirin group. Significantly fewer patients within the Viramidine group developed anemia compared with the ribavirin group (4\% vs $27 \%$ ) [60]. Unfortunately, two phase 3 trials (VISER 1 and VISER 2) comparing Viramidine plus peginterferon alfa-2a or peginterferon alfa-2b showed that sustained virological response rates in the Viramidine group were inferior to those in the ribavirin group [61].

Current standard HCV treatment demonstrated that HCV infection can be eliminated by agents that stimulate the host innate and adaptive immunity. Toll-like receptors are pathogen recognition receptors expressed by immune cells that initiate the innate immune response after stimulation. Signaling through Toll-like receptors induces the production of type 1 T-helper cells, promotes cytokine and chemokine production, and stimulates natural killer cells [62]. Synthetic Toll-like receptor agonists are potentially able to alter the HCV RNA load by mimicking the immune response observed during the course of acute $\mathrm{HCV}$ infections.

\section{Conclusions}

Currently, peginterferon- $\alpha$ and nucleoside/nucleotide analogues are the only treatment options for chronic hepatitis B, but they have suboptimal responses and substantial side effects. Promising drugs are in late stages of development, ready to be approved. Due to the advances in cell culture systems, our understanding of the HCV life cycle has developed tremendously over the past few years. Every phase of the HCV life cycle forms a potential target for antiviral therapy. As mentioned above, many of the STAT-C drugs are currently being tested in clinical trials. Some trials showed excellent results and form the basis of our optimism for finding more efficient therapies against HCV in the near future. However, side effects and viral resistance remain serious problems encountered in several clinical trials and continue to present a major challenge for the development of potential novel therapeutic agents.

\section{Clinical Trials Acronyms}

PROVE-Investigation of HCV Protease Inhibition for Viral Eradication; VISER-Viramidine's Safety and Efficacy vs Ribavirin.

\section{Acknowledgments}

Both Dr. Takkenberg and Dr. de Bruijne contributed equally to this manuscript.

\section{Disclosures}

Dr. Reesink is a consultant for Schering-Plough and has received research grants from Schering-Plough, Vertex, Roche, Gilead, and UCB. 
References and Recommended Reading

Papers of particular interest, published recently, have been highlighted as:

- Of importance

$\bullet \quad$ Of major importance

1. World Health Organization: The World Health Report 1997: Conquering Suffering, Enriching Humanity. Geneva, Switzerland: World Health Organization; 1997.

2. Perz JF, Armstrong GL, Farrington LA, et al.: The contributions of hepatitis $B$ virus and hepatitis $C$ virus infections to cirrhosis and primary liver cancer worldwide. $J$ Hepatol 2006, 45:529-538.

3. Goldstein ST, Zhou F, Hadler SC, et al.: A mathematical model to estimate global hepatitis $B$ disease burden and vaccination impact. Int J Epidemiol 2005, 34:1329-1339.

4. World Health Organization: Hepatitis B fact sheet No. 204. http://www.who.int/mediacentre/factsheets/fs204/en/print. html. Updated October 2000. Accessed October 30, 2007.

5. Hoofnagle JH, Doo E, Liang TJ, et al.: Management of hepatitis B: summary of a clinical research workshop. Hepatology 2007, 45:1056-1075.

6. Lok AS, McMahon BJ: Chronic hepatitis B. Hepatology 2007, 45:507-539.

7. de Franchis R, Meucci G, Vecchi M, et al.: The natural history of asymptomatic hepatitis B surface antigen carriers. Ann Intern Med 1993, 118:191-194.

8. Wong DK, Cheung AM, O'Rourke K, et al.: Effect of alpha-interferon treatment in patients with hepatitis B e antigen-positive chronic hepatitis $\mathrm{B}$. A meta-analysis. Ann Intern Med 1993, 119:312-323.

9. Schalm SW, Heathcote J, Cianciara J, et al.: Lamivudine and alpha interferon combination treatment of patients with chronic hepatitis B infection: a randomised trial. Gut 2000, 46:562-568.

10. Lau GK, Piratvisuth T, Luo KX, et al.: Peginterferon alfa2a, lamivudine, and the combination for $\mathrm{HBeAg}$-positive chronic hepatitis B. N Engl J Med 2005, 352:2682-2695.

11. Janssen HL, van Zonneveld M, Senturk H, et al.: Pegylated interferon alfa-2b alone or in combination with lamivudine for HBeAg-positive chronic hepatitis B: a randomised trial. Lancet 2005, 365:123-129.

12. Dienstag JL, Schiff ER, Wright TL, et al.: Lamivudine as initial treatment for chronic hepatitis B in the United States. N Engl J Med 1999, 341:1256-1263.

13. Marcellin P, Chang TT, Lim SG, et al.: Adefovir dipivoxil for the treatment of hepatitis $\mathrm{B}$ e antigen-positive chronic hepatitis B. N Engl J Med 2003, 348:808-816.

14.•• Chang TT, Gish RG, de Man R, et al.: A comparison of entecavir and lamivudine for $\mathrm{HBeAg}$-positive chronic hepatitis B. N Engl J Med 2006, 354:1001-1010.

This study demonstrated the strong antiviral effect of entecavir in HbeAg-positive chronic hepatitis B patients with a very good resistance profile and led to its registration for chronic hepatitis $\mathrm{B}$.

15. Lai CL, Leung N, Teo EK, et al.: A 1-year trial of telbivudine, lamivudine, and the combination in patients with hepatitis B e antigen-positive chronic hepatitis B. Gastroenterology 2005, 129:528-536.

This study demonstrated that telbivudine is a good option in HBeAg-positive patients with strong HBV reduction, but with a suboptimal annual resistance rate.

16. Marcellin P, Lau GK, Bonino F, et al.: Peginterferon alfa-2a alone, lamivudine alone, and the two in combination in patients with HBeAg-negative chronic hepatitis B. N Engl J Med 2004, 351:1206-1217.

17. Hadziyannis SJ, Tassopoulos NC, Heathcote EJ, et al.: Adefovir dipivoxil for the treatment of hepatitis $B$ e antigen-negative chronic hepatitis B. N Engl J Med 2003, 348:800-807.

18. Lai CL, Shouval D, Lok AS, et al.: Entecavir versus lamivudine for patients with $\mathrm{HBeAg-negative} \mathrm{chronic} \mathrm{hepatitis} B$. N Engl J Med 2006, 354:1011-1020.
19. Cooksley WG, Piratvisuth T, Lee SD, et al.: Peginterferon alpha-2a (40 kDa): an advance in the treatment of hepatitis B e antigen-positive chronic hepatitis B. J Viral Hepat 2003, 10:298-305.

20. Gish RG, Lau DT, Schmid P, Perrillo R: A pilot study of extended duration peginterferon alfa-2a for patients with hepatitis $\mathbf{B}$ e antigen-negative chronic hepatitis B. Am J Gastroenterol 2007, [Epub ahead of print].

21. Tassopoulos NC, Volpes R, Pastore G, et al.: Efficacy of lamivudine in patients with hepatitis $\mathrm{B}$ e antigen-negative/ hepatitis B virus DNA-positive (precore mutant) chronic hepatitis B. Lamivudine Precore Mutant Study Group. Hepatology 1999, 29:889-896.

22. Sherman M, Yurdaydin C, Sollano J, et al.: Entecavir for treatment of lamivudine-refractory, $\mathrm{HBeAg}$-positive chronic hepatitis B. Gastroenterology 2006, 130:2039-2049.

23. Peters MG, Hann HH, Martin P, et al.: Adefovir dipivoxil alone or in combination with lamivudine in patients with lamivudine-resistant chronic hepatitis B. Gastroenterology 2004, 126:91-101.

24. Rapti I, Dimou E, Mitsoula P, Hadziyannis SJ: Adding-on versus switching-to adefovir therapy in lamivudine-resistant HBeAg-negative chronic hepatitis B. Hepatology 2007, 45:307-313.

25. Dore GJ, Cooper DA, Pozniak AL, et al.: Efficacy of tenofovir disoproxil fumarate in antiretroviral therapy-naive and -experienced patients coinfected with HIV-1 and hepatitis B virus. J Infect Dis 2004, 189:1185-1192.

26. Peters MG, Andersen J, Lynch P, et al.: Randomized controlled study of tenofovir and adefovir in chronic hepatitis B virus and HIV infection: ACTG A5127. Hepatology 2006, 44:1110-1116.

27.• van Bommel F, Zollner B, Sarrazin C, et al.: Tenofovir for patients with lamivudine-resistant hepatitis $B$ virus (HBV) infection and high HBV DNA level during adefovir therapy. Hepatology 2006, 44:318-325.

This small study demonstrated that tenofovir is also a serious option in lamivudine-refractory chronic hepatitis B patients. Larger studies are under way and will likely lead to the registration of tenofovir for chronic hepatitis B.

28. van Bommel F, Wunsche T, Mauss S, et al.: Comparison of adefovir and tenofovir in the treatment of lamivudineresistant hepatitis B virus infection. Hepatology 2004, 40:1421-1425.

29. Lim SG, Ng TM, Kung N, et al.: A double-blind placebocontrolled study of emtricitabine in chronic hepatitis B. Arch Intern Med 2006, 166:49-56.

30. Yoo BC, Kim JH, Chung YH, et al.: Twenty-four-week clevudine therapy showed potent and sustained antiviral activity in HBeAg-positive chronic hepatitis B. Hepatology 2007, 45:1172-1178.

31. Yoo BC, Kim JH, Kim TH, et al.: Clevudine is highly efficacious in hepatitis $\mathrm{B}$ e antigen-negative chronic hepatitis $\mathrm{B}$ with durable off-therapy viral suppression. Hepatology 2007, 46:1041-1048.

32. Lin CC, Xu C, Teng A, et al.: Pharmacokinetics of pradefovir and PMEA in healthy volunteers after oral dosing of pradefovir. J Clin Pharmacol 2005, 45:1250-1258.

33. Lai CL, Brown NA, Myers M: Valtorcitabine provides potent suppression of hepatitis B virus in patients with chronic hepatitis: results of a phase I/II clinical trial. Hepatology 2004, 40:173A.

34. Fried MW, Shiffman ML, Reddy KR, et al.: Peginterferon alfa-2a plus ribavirin for chronic hepatitis $\mathrm{C}$ virus infection. N Engl J Med 2002, 347:975-982.

35. Manns MP, McHutchison JG, Gordon SC, et al.: Peginterferon alfa- $2 \mathrm{~b}$ plus ribavirin compared with interferon alfa-2b plus ribavirin for initial treatment of chronic hepatitis C: a randomised trial. Lancet 2001, 358:958-965.

36. Lohmann V, Korner F, Koch J, et al.: Replication of subgenomic hepatitis C virus RNAs in a hepatoma cell line. Science 1999, 285:110-113. 
37.• Lindenbach BD, Evans MJ, Syder AJ, et al.: Complete replication of hepatitis $\mathrm{C}$ virus in cell culture. Science 2005, 309:623-626.

This study describes the progress of the replication and virus particle production of a full-length HCV genome. The reproduction of infectious virus particles in cell culture has led to a major progression in our understanding of the HCV life cycle and stimulated the production of novel HCV therapies.

38. Pawlotsky JM: Current and future concepts in hepatitis C therapy. Semin Liver Dis 2005, 25:72-83.

39. Penin F: Structural biology of hepatitis C virus. Clin Liver Dis 2003, 7:1-21.

40. Hsu M, Zhang J, Flint M, et al.: Hepatitis C virus glycoproteins mediate $\mathrm{pH}$-dependent cell entry of pseudotyped retroviral particles. Proc Natl Acad Sci U S A 2003, 100:7271-7276.

41. Perez-Berna AJ, Moreno MR, Guillen J, et al.: The membrane-active regions of the hepatitis $\mathrm{C}$ virus $\mathrm{E} 1$ and $\mathrm{E} 2$ envelope glycoproteins. Biochemistry 2006, 45:3755-3768.

42. Flint $\mathrm{M}, \mathrm{McKeating} \mathrm{JA}$ : The role of the hepatitis $\mathrm{C}$ virus glycoproteins in infection. Rev Med Virol 2000, 10:101-117.

43. Eren R, Landstein D, Terkieltaub D, et al.: Preclinical evaluation of two neutralizing human monoclonal antibodies against hepatitis $\mathrm{C}$ virus (HCV): a potential treatment to prevent HCV reinfection in liver transplant patients. J Virol 2006, 80:2654-2664.

44. Davis GL, Nelson DR, Terrault N, et al.: A randomized, open-label study to evaluate the safety and pharmacokinetics of human hepatitis C immune globulin (Civacir) in liver transplant recipients. Liver Transpl 2005, 11:941-949.

45. Hanecak R, Brown-Driver V, Fox MC, et al.: Antisense oligonucleotide inhibition of hepatitis $\mathrm{C}$ virus gene expression in transformed hepatocytes. J Virol 1996, 70:5203-5212.

46. McHutchison JG, Patel K, Pockros P, et al.: A phase I trial of an antisense inhibitor of hepatitis $C$ virus (ISIS 14803), administered to chronic hepatitis $\mathrm{C}$ patients. J Hepatol 2006, 44:88-96.

47. Otto GA, Puglisi JD: The pathway of HCV IRES-mediated translation initiation. Cell 2004, 119:369-380.

48. Kato T, Miyamoto M, Furusaka A, et al.: Processing of hepatitis $\mathrm{C}$ virus core protein is regulated by its $\mathrm{C}$-terminal sequence. J Med Virol 2003, 69:357-366.

49. Lamarre D, Anderson PC, Bailey M, et al.: An NS3 protease inhibitor with antiviral effects in humans infected with hepatitis C virus. Nature 2003, 426:186-189.

50. Reesink HW, Zeuzem S, Weegink CJ, et al.: Rapid decline of viral RNA in hepatitis C patients treated with VX-950: a phase Ib, placebo-controlled, randomized study. Gastroenterology 2006, 131:997-1002.

This phase $1 \mathrm{~b}$ randomized trial tested telaprevir in chronic HCV patients with genotype 1 , of whom $79 \%$ had failed prior treatment. Results showed a median $-4.4 \log _{10}$ reduction in HCV RNA levels after 14 days of treatment in the optimal-dose group.

51. Sarrazin C, Kieffer TL, Bartels D, et al.: Dynamic hepatitis $\mathrm{C}$ virus genotypic and phenotypic changes in patients treated with the protease inhibitor telaprevir. Gastroenterology 2007, 132:1767-1777.
52.• Forestier N, Reesink HW, Weegink CJ, et al.: Antiviral activity of telaprevir (VX-950) and peginterferon alfa-2a in patients with hepatitis C. Hepatology 2007, 46:640-648.

This study tested telaprevir alone, peginterferon alfa-2a with placebo, and telaprevir with peginterferon alfa-2a for 14 days, followed by 12 weeks of off-study standard therapy. Results showed a median HCV RNA decline of $-5.5 \log _{10}$ after 14 days in the telaprevir and peginterferon alfa-2a group. Twelve-week results of standard therapy showed undetectable HCV RNA levels in all eight patients in the telaprevir and peginterferon alfa-2a group, without the observation of viral breakthroughs.

53. Sarrazin C, Rouzier R, Wagner F, et al.: SCH 503034, a novel hepatitis $C$ virus protease inhibitor, plus pegylated interferon alpha-2b for genotype 1 nonresponders. Gastroenterology 2007, 132:1270-1278.

54. Bartenschlager R, Frese M, Pietschmann T: Novel insights into hepatitis $\mathrm{C}$ virus replication and persistence. Adv Virus Res 2004, 63:71-180.

55. Afdhal N, O'Brien C, Godofsky E, et al.: Valopicitabine (NM283), alone or with peginterferon, compared to peginterferon/ribavirin (pegIFN/RBV) re-treatment in hepatitis $\mathrm{C}$ patients with prior non-response to pegIFN/RBV: week 24 results [abstract]. Presented at the 41st Annual Meeting of the European Association for the Study of the Liver. April 26-30, 2006; Vienna, Austria.

56. Roberts S, Cooksley G, Dore GJ, et al.: Results of a phase $1 \mathrm{~b}$, multiple dose study of R1626, a novel nucleoside analogue, targeting HCV polymerase in chronic HCV genotype 1 patients [abstract]. Presented at the 57th Annual Meeting of the American Association for the Study of Liver Diseases. October 27-31, 2006; Boston, MA.

57. Steinmann E, Whitfield T, Kallis S, et al.: Antiviral effects of amantadine and iminosugar derivatives against hepatitis C virus. Hepatology 2007, 46:330-338.

58. Whitby K, Taylor D, Patel D, et al.: Action of celgosivir (6 O-butanoyl castanospermine) against the pestivirus BVDV: implications for the treatment of hepatitis C. Antivir Chem Chemother 2004, 15:141-151.

59. Durantel D, Carrouee-Durantel S, Branza-Nichita N, et al.: Effects of interferon, ribavirin, and iminosugar derivatives on cells persistently infected with noncytopathic bovine viral diarrhea virus. Antimicrob Agents Chemother 2004, 48:497-504.

60. Gish RG, Arora S, Rajender RK, et al.: Virological response and safety outcomes in therapy-naive patients treated for chronic hepatitis $\mathrm{C}$ with taribavirin or ribavirin in combination with pegylated interferon alfa-2a: a randomized, phase 2 study. J Hepatol 2007, 47:51-59.

61. Valeant Pharmaceuticals reports VISER2 results for Viramidine [press release]. Costa Mesa, CA: Valeant Pharmaceuticals International; September 12, 2006.

62. Janeway CA, Jr, Medzhitov R: Innate immune recognition. Annu Rev Immunol 2002, 20:197-216. 